\title{
The Influence of Leadership Style, Organizational Culture, and Job Satisfaction on Employee Performance Department of Education and Culture of Yapen Islands
}

\author{
Edison Musa Kayoi ${ }^{1}$, Bonifasia Elita Bharanti ${ }^{2}$, Sri Listyarini ${ }^{3}$ \\ 1,2,3Faculty of Economics, Universitas Terbuka, Indonesia \\ Email: kayoiedison@gmail.com, elitabharanti@gmail.com, listyarini@ecampus.ut.ac.id
}

\begin{abstract}
:
The Department of Education and Culture of the Yapen Islands Regency as an extension of the local government in dealing with education has attempted to provide maximum public services. However, in its implementation, there are several obstacles, including not optimal services provided due to less-than-optimal employee performance. The objective of the study is to analyze the influence of leadership style, organizational culture, and job satisfaction on the performance of the employees of the Department of Education and Culture of the Yapen Islands Regency. Collecting data used a questionnaire. The research sample was calculated using the Slovin formula and obtained a total sample of 60 employees of the Department of Education and Culture of the Yapen Islands Regency. The data were tested with research instrument tests, classical assumption tests, and multiple linear regression tests using SPSS software version 25. The results showed that 1) leadership style had a positive and significant effect on employee performance, 2) organizational culture had a positive and significant effect on the performance of employees, 3) job satisfaction has no effect on employee performance
\end{abstract}

Keywords: leadership style; organizational culture; job satisfaction; employee performance

\section{Introduction}

The implementation of good governance requires the development and implementation of an appropriate, clear, measurable and legal accountability system; hence, government administration and development can take place in an efficient, effective, clean and responsible manner (Nanwani \& McIntyre, 2019). Government organizations are required to have good performance in order to realize good governance (Bird, 2001). When government organizations have good performance, it will have a good impact on people's lives and restore public confidence in the government (Asencio, 2016).

The main resources in public services are human resources which include staff employed, expertise, problem-solving capacity and ability to implement policies (Arnaboldi et al., 2015). Therefore, managing human resources is important and must be considered by every agency in order to improve employee and organizational performance (Nasution, 2019). Performance can be interpreted as the importance of a job, a person's required skill level, ability, progress, and completion rate of a job (Panggabean, 2002). Good employee performance becomes useful and desirable in organizations because it can increase the effectiveness of organizational goals, not least for the Department of Education and Culture of the Yapen Islands Regency, because employee performance affects the success of the agency in achieving its goals (Puluhulawa, 2013). It can be seen from various phenomena that occur such as the dissatisfaction of teachers due to obstacles related to the service such as promotions, incentive problems, and matters relating to school needs (Liana, 2012). In facing these challenges, reliable human resources are needed because employee performance will affect the high and low productivity of the agency (Patterson et al., 2004). 
Based on the archives of the Department of Education and Culture of the Yapen Islands Regency, the attendance rate of employees of the Education and Culture Office is quite low as seen from the high percentage of permits, leaving early, being late, and being absent only once. The low level of attendance can affect the achievement of good service performance, because the more absent employees are, the more work targets that must be completed are not achieved. Hence, all employees can achieve the desired performance, many factors may influence one of them is leadership style, where this leadership style can affect employee behaviors in an organization (Pawirosumarto et al., 2017).

The 2019 Yapen Islands Regency Education and Culture Office's Performance Accountability Report (LAKIP) explained the position, main tasks, and functions of the Education and Culture Office. The position of the service is an element of implementing government affairs in the field of education which is the authority of the region. The service is led by the head of the service who is under and responsible to the regent through the regional secretary. The leadership of an office head has the task of helping the regent carry out government affairs in the field of education which is the authority of the region and the assistance tasks given to the district (Rahmatiah et al., 2019).

Based on previous studies that examined the influence of leadership style, organizational culture, and job satisfaction on employee performance, it was found that there were differences in research results between one researcher and another, known as the research gap. The existence of this research gap provides an opportunity for researchers to conduct further research on the effect of each variable on employee performance. Ohemeng et al. (2018) and Ugheoke (2019) found a significant positive effect of leadership style on employee performance. Meanwhile, research by Ogbonna and Harris (2000) and Wibowo and Saputra (2017) found that leadership style did not have a significant effect on employee performance. Moreover, Fithriana and Adi (2017) and Lolowang et al. (2019) found a positive influence of organizational culture on employee performance, while Syauta et al. (2012) discovered the opposite, organizational culture does not have a significant influence on employee performance. Furthermore, Siengthai and Pila-Ngarm (2016) and Hendri (2019) revealed that job satisfaction had a significant positive effect on employee performance, while Crossman and Abou-Zaki (2003) found job satisfaction did not affect employee performance.

Given the phenomena related to employee performance and the research gap of previous studies, the researchers are interested in seeing the importance of applying leadership style, organizational culture, and job satisfaction to improving employee performance, especially at the Education and Culture Department of Yapen Islands Regency. The objective of this study is to analyze the effect of leadership style, organizational culture, and job satisfaction on employee performance.

\section{Review of Literature}

\subsection{Performance}

Improving the performance of government institutions has become an important issue in recent decades (Vermeeren et al., 2013). Performance is a quantitative and qualitative expression where the work performed by individuals, groups or companies can achieve goals (Leković \& Marić, 2015). In line with the opinion of Prawirosentono (2014), performance is the result of work that individuals or groups achieve in the organization as an effort to achieve legally relevant goals, in accordance with their rights and responsibilities without violating the law and morals or ethics. 
Performance is a concept that describes how a person can use his own potential or real knowledge, skills and abilities to be able to achieve his own goals or expectations (Altındağ \& Kösedağ1, 2015). Gibson et al. (1996) explained that the ability and motivation of employees in conducting their duties also determine performance. Employee performance measurement is useful for improving the quality and accountability of decision-making and is useful for evaluating goals and objectives (Whittaker, 1995).

\subsection{Leadership Style}

Leadership is the ability of individuals to influence a group to achieve goals (Robbins \& Coulter, 2010). Leaders are considered to be the main drivers of performance in the public sector and organizations (Brewer \& Selden, 2000). Choosing the right leadership style is an important factor because it affects performance both at the organizational and individual levels (Sauer, 2011). Leadership style and job satisfaction of subordinates have been shown to affect employee performance (Spector, 2000). Thus, it is important to adopt a leadership style that is suitable for the organization so that the organization can achieve its goals effectively and efficiently (Babalola, 2016). The organizational system created by the leader will determine the success of employee performance profitably or unfavorably (Ibrahim et al., 2017).

When a leader has a leadership style that is appropriate and liked by employees, it will be able to improve employee performance (Erniwati et al., 2020). An effective leadership style will inspire and empower employees so that they will be able to produce a very high level of effort, commitment, and willingness of employees to take risks and provide better performance for the organization (Ohemeng et al., 2018). Ugheoke (2019) examined organizational culture at the Ministry of Higher Education in Oman and found that bureaucratic culture and supportive culture have a positive and significant impact on employee performance in the public sector. Other studies also found a positive and significant influence of organizational culture on employee performance (Erniwati et al., 2020; Ohemeng et al., 2018; Zeb et al., 2015). Referring to the theory and previous empirical findings, the first hypothesis proposed in this study is:

H1: It is suspected that there is a positive and significant influence of leadership style on employee performance.

\subsection{Organizational Culture}

Organizational culture has a major influence on individual behavior in organizations (Barney, 1986; Trice \& Beyer, 1993). A good culture will ensure that employees know exactly what the organization expects of them (Budhwar \& Sparrow, 1998). Brown (1998) defined organizational culture as the beliefs, values, and methods for effectively addressing the experiences that developed throughout the history of the organization and demonstrating them in the regulation of member behavior within the organization. According to Ravasi and Schultz (2006), organizational culture is a set of mental tendencies that guide interpretation and action in organizations. If an organization has a strong culture, it can bring the organization to develop in a better direction (Robbins, 2006).

When organizational culture can support participation, it will result in job satisfaction which encourages employees to be more creative in improving their performance (Erniwati et al., 2020). Fithriana and Adi (2017) discovered that organizational culture has the most dominant influence on employee performance in the Malang City Government. Lolowang et al. (2019) found a positive and significant influence of organizational culture applied to employee performance at the Jayapura Village Office. Furthermore, several other researchers also found that organizational culture has a positive and significant effect on employee 
performance (Altındağ \& Kösedağ1, 2015; Asria \& Amali, 2018; Sulaefi, 2019; Ugheoke, 2019). Therefore, the second hypothesis proposed is:

H2: It is suspected that there is a positive and significant influence between organizational culture on employee performance

\subsection{Job Satisfaction}

Job satisfaction is a positive emotional state of evaluating one's work experience (Mathis \& Jackson, 2011). According to Bailey et al. (1991), job satisfaction is a person's level of feeling either positive or negative towards their work. Meanwhile, the notion of job satisfaction according to Kreitner and Kinichi (1992) is an effective or emotional response that leads to a job. Job satisfaction also refers to the extent to which individual needs and values are met by the work environment and how individuals respond to that environment (Tewksbury \& Higgins, 2006).

Employee satisfaction with his current job will make employees feel that their work is important and affect employee integrity which is manifested in honesty in working in accordance with company regulations (Hendri, 2019). Erniwati et al. (2020) found that job satisfaction has a positive effect on employee performance at the Regional Secretariat of South Sulawesi Province, if job satisfaction is high, employees will show a positive attitude towards their work and produce high performance. Other previous studies conducted by Ali and Farooqi (2014) and Mira et al. (2019) also found a positive effect of job satisfaction on employee performance. Therefore, referring to the previous empirical findings, the third hypothesis proposed is:

H3: It is suspected that there is a positive and significant effect between job satisfaction on employee performance.

The three hypotheses proposed in this study are summarized in the following research model (Figure 1).

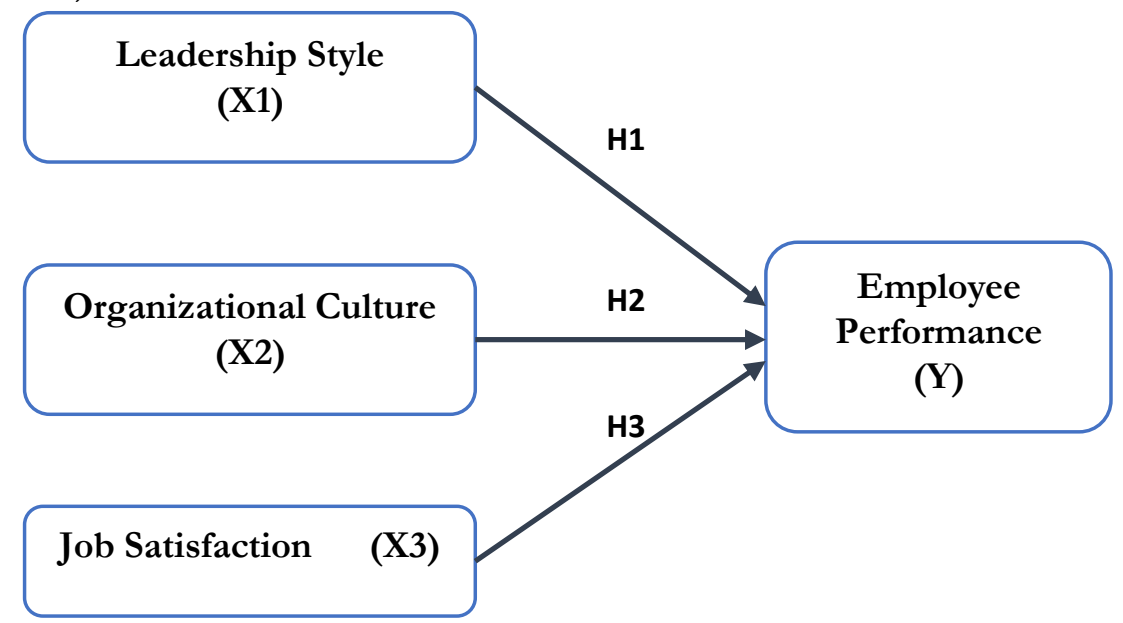

Figure 1. Research Model 


\section{Research Methods}

This research used a quantitative approach with the type of causality research, which is to reveal the causal effect between variables and to prove the research hypothesis. The population of this study were all employees at the Department of Education and Culture of the Yapen Islands Regency. The sample is calculated using the Slovin formula so that the resulting number of samples is 60 employees. The research instrument used to collect data was a questionnaire that was prepared on a 5 -point Likert scale from 1-strongly disagree to 5strongly agree. The data of this research were analyzed using multiple linear regression analysis method. Previously, the data was first tested for validity and reliability. Then, the classical assumption test was performed which included normality, multicollinearity, and heteroscedasticity tests. There are three independent variables in this study, namely leadership style, organizational culture, and job satisfaction, and one dependent variable, which is employee performance.

\section{Results and Discussion}

Characters of respondents that will be discussed include gender, age, education and years of service. The presentation of the respondent's characteristic data aims to identify the special characteristics of the respondent so that it is easier for researchers to conduct analysis. Based on table 1, it can be concluded that the majority of employees at the Education and Culture Department of Yapen Islands Regency are male, aged 36-40 years, and with the highest level of education, which is high school or equivalent. The number of employees with the latest high school education level reflects the poor quality of education of employees. However, if employees have the appropriate skills and expertise, they are still expected to be able to provide the best performance.

Table 1. Descriptive Characteristics of Respondents

\begin{tabular}{cccc}
\hline Category & Alternative Answer & $\begin{array}{c}\text { Number of } \\
\text { Respondents }\end{array}$ & $\begin{array}{c}\text { Percentage } \\
\mathbf{( \% )}\end{array}$ \\
\hline \multirow{2}{*}{ Sex } & Male & 31 & $51,7 \%$ \\
& Female & 29 & $48,3 \%$ \\
\hline \multirow{2}{*}{ Age } & $18-25$ year old & 2 & $3,3 \%$ \\
& $31-35$ year old & 11 & $18,3 \%$ \\
& $36-40$ year old & 28 & $46,7 \%$ \\
Educational & $>40$ yeard old & 19 & $31,7 \%$ \\
Background & High School & 30 & $50,0 \%$ \\
& Diploma 3 & 8 & $13,3 \%$ \\
& Bachelor Degree & 19 & $31,7 \%$ \\
& Master Degree & 3 & $5,0 \%$ \\
\hline
\end{tabular}

Descriptions of respondents' answers are used to determine the opinions or perceptions given by respondents on each variable of leadership style, organizational culture, and job satisfaction on employee performance. Therefore, an analysis was performed to calculate the average value of the results of respondents' responses to each question. The results of the respondent's answers were categorized by calculating the maximum value minus the minimum value then divided by the number of class 5 , so that the interval results were 0.8 (Riduwan, 2002). With an interval of 0.80 , the categorization system is as follows: $1.00-1.80$ (very low); 1.81-2.60 (low); 2.61-3.40 (moderate); 3,41-4.20 (high); and 4.21-5.00 (very high). From table 2, it can be seen that all variables have an average value that is in the high category. 
The average value of leadership style is 3.75 , work culture is 3.47 , job satisfaction is 3.54 , and employee performance is 3.58 .

Table 2. Distribution of Respondents' Opinions

\begin{tabular}{|c|c|c|c|c|}
\hline Item & Leadership Style (X1) & Total & Mean & Category \\
\hline $\mathrm{X} 1.1$ & I respect and trust the leader & 217 & 3,62 & High \\
\hline $\mathrm{X} 1.2$ & My boss can be a good example at work & 212 & 3,53 & High \\
\hline $\mathrm{X} 1.3$ & My boss often gives motivation & 222 & 3,70 & High \\
\hline $\mathrm{X} 1.4$ & $\begin{array}{l}\text { Leaders really support innovation and } \\
\text { creativity of employees }\end{array}$ & 226 & 3,77 & High \\
\hline $\mathrm{X} 1.5$ & $\begin{array}{l}\text { Leaders always listen to input and pay } \\
\text { attention to employee needs }\end{array}$ & 233 & 3,88 & High \\
\hline X1.6 & Leaders give awards to employees who excel & 247 & 4,12 & High \\
\hline $\mathrm{X} 1.7$ & $\begin{array}{l}\text { Leaders always direct employees according to } \\
\text { standards }\end{array}$ & 223 & 3,72 & High \\
\hline $\mathrm{X} 1.8$ & My boss intervenes if standards are not met & 218 & 3,63 & High \\
\hline & Average & & 3,75 & High \\
\hline $\mathrm{X} 2.1$ & $\begin{array}{l}\text { I am encouraged to have the initiative in } \\
\text { getting work done }\end{array}$ & 205 & 3,42 & High \\
\hline $\mathrm{X} 2.2$ & I am encouraged to think creatively & 204 & 3,40 & Moderate \\
\hline $\mathrm{X} 2.3$ & $\begin{array}{l}\text { I am given full confidence in completing the } \\
\text { work }\end{array}$ & 213 & 3,55 & High \\
\hline $\mathrm{X} 2.4$ & I am required to complete work accurately & 206 & 3,43 & High \\
\hline $\mathrm{X} 2.5$ & $\begin{array}{l}\text { The leader motivates me to pay more } \\
\text { attention to detail in doing my job }\end{array}$ & 216 & 3,60 & High \\
\hline $\mathrm{X} 2.6$ & $\begin{array}{l}\text { The organization makes employees feel that } \\
\text { they are the most important asset }\end{array}$ & 201 & 3,35 & Moderate \\
\hline $\mathrm{X} 2.7$ & $\begin{array}{l}\text { Organizations always encourage employees to } \\
\text { increase their competitive advantage }\end{array}$ & 211 & 3,52 & High \\
\hline $\mathrm{X} 2.8$ & $\begin{array}{l}\text { Employees care about problems faced by the } \\
\text { organization and create solutions to solve } \\
\text { them }\end{array}$ & 210 & 3,50 & High \\
\hline & Average & & 3,47 & High \\
\hline $\mathrm{X} 3.1$ & Work done according to your wishes. & 216 & 3,60 & High \\
\hline $\mathrm{X} 3.2$ & $\begin{array}{l}\text { You get the opportunity to use your own } \\
\text { method in completing the given task. }\end{array}$ & 207 & 3,45 & High \\
\hline $\mathrm{X} 3.3$ & $\begin{array}{l}\text { The benefits provided by the government are } \\
\text { in accordance with the workload. }\end{array}$ & 208 & 3,47 & High \\
\hline X3.4 & $\begin{array}{l}\text { The benefits received are in accordance with } \\
\text { government regulations ketentuan }\end{array}$ & 214 & 3,57 & High \\
\hline $\mathrm{X} 3.5$ & The office designs a clear career path for you. & 210 & 3,50 & High \\
\hline X3.6 & $\begin{array}{l}\text { Bosses are able to provide direction } \\
\text { according to your abilities and skills }\end{array}$ & 209 & 3,48 & High \\
\hline $\mathrm{X} 3.7$ & Have solid co-workers in working together & 214 & 3,57 & High \\
\hline $\mathrm{X} 3.8$ & Good communication with co-workers & 219 & 3,65 & High \\
\hline \multicolumn{3}{|c|}{ Average } & 3,54 & High \\
\hline Y1 & $\begin{array}{l}\text { You carry out work in accordance with } \\
\text { applicable regulatory procedures }\end{array}$ & 212 & 3,53 & High \\
\hline Y2 & You are able to complete any given job. & 197 & 3,28 & Moderate \\
\hline Y3 & $\begin{array}{l}\text { You are able to achieve the specified job } \\
\text { target }\end{array}$ & 207 & 3,45 & High \\
\hline
\end{tabular}




\begin{tabular}{clrrr} 
Y4 & $\begin{array}{l}\text { You have the skills needed to get the job } \\
\text { done }\end{array}$ & 206 & 3,43 & High \\
$\begin{array}{l}\text { You are able to work together with a team in } \\
\text { Yompleting the work that must be done } \\
\text { together }\end{array}$ & 222 & 3,70 & High \\
Y6 & $\begin{array}{l}\text { You can be trusted in completing the given } \\
\text { job }\end{array}$ & 216 & 3,60 & High \\
Y7 & $\begin{array}{l}\text { You are able to do the work independently. } \\
\text { You put work interests above personal }\end{array}$ & 226 & 3,77 & High \\
interests & 230 & 3,83 & High \\
\hline & Average & & $\mathbf{3 , 5 8}$ & High \\
\hline
\end{tabular}

Information: X1 = Leadership Style; X2 = Organizational Culture; X3 = Job Satisfaction; Y = Employee Performance.

Furthermore, the data is first tested for validity and reliability. Validity test is a test to see whether the research instrument is valid or not. The research instrument or questionnaire meets the validity test if the questionnaire questions can represent what is measured by the questionnaire (Ghozali, 2011). The questionnaire is said to be valid if it has an r-statistical value $>$ r-table (0.254). From the test results in Table 3, it can be seen that all items in the four variables have an r-statistical value $>0.254$. Therefore, it can be concluded that all variable items are valid.

Reliability test is used to measure the level of reliability of a research instrument consisting of variable indicators. The questionnaire is declared reliable if the respondent's answer to the statement is consistent or stable from time to time (Ghozali, 2011). To measure reliability, it used Cronbach Alph statistical test. A variable is said to be reliable if it gives a Cronbach Alpha value $>0.60$. The results of the reliability test in Table 3 show that all variables have a Cronbach Alpha coefficient value greater than 0.60. Therefore, it can be concluded that all variables are reliable and can be used to measure the variables in this study.

Table 3. Validity and Reliability Test Results

\begin{tabular}{ccc}
\hline Item & R Statistic & Cronbach's Alpha \\
\hline Leadership Style & & 0,942 \\
X1.1 & 0,941 & \\
X1.2 & 0,940 & \\
X1.3 & 0,884 & \\
X1.4 & 0,847 & \\
X1.5 & 0,859 & \\
X1.6 & 0,403 & \\
X1.7 & 0,941 & \\
X1.8 & 0,940 & \\
X2.1 & & \\
X2.2 & 0,857 & \\
X2.3 & 0,902 & \\
X2.4 & 0,919 & \\
X2.5 & 0,790 & \\
X2.6 & 0,863 & \\
X2.7 & 0,760 & \\
X2.8 & 0,857 & \\
\hline
\end{tabular}




\begin{tabular}{ccc}
\hline Job Satisfaction & 0,880 & 0,946 \\
X3.1 & 0,862 & \\
X3.2 & 0,820 & \\
X3.3 & 0,861 & \\
X3.4 & 0,861 & \\
X3.5 & 0,824 & \\
X3.6 & 0,876 & \\
X3.7 & 0,8503 \\
X3.8 & & \\
\hline Employee Performance & 0,632 & \\
X3.8 & 0,602 & \\
X3.8 & 0,622 & \\
X3.8 & 0,582 & \\
X3.8 & 0,692 & \\
X3.8 & 0,728 & \\
X3.8 & 0,728 & \\
X3.8 & 0,615 & \\
X3.8 & & \\
\hline
\end{tabular}

The classical assumption test consists of testing for normality, multicollinearity, and heteroscedasticity. The normality test is a test used to determine whether the residual variable in the regression model has a normal distribution. The results of the normality test using the Kolmogorov Smirnov formula show the Asymp value. Sig $>0.05$, thus, it can be concluded that it has fulfilled the normality assumption. Then, the multicollinearity test aims to test whether a regression model has a correlation between the independent variables. To determine whether there is multicollinearity, it was by looking at the tolerance value and variance inflation factor (VIF). If the tolerance value is $>0.10$, or equal to the VIF value $<10$, the regression model used in this study is free from multicollinearity (Ghozali, 2011). Based on Table 4, all independent variables have a tolerance value $>0.10$ and a VIF value $<10$, thus, in this study there is no multicollinearity problem. Heteroscedasticity test was conducted to test whether in the regression model there was an inequality of variance from the residual of one observation to another observation. The heteroscedasticity test was performed using the Park test method, which regressed the residual value with each independent variable. The test results in Table 4 show that all independent variables have a significance value $>0.05$. Hence, it can be concluded that there is no heteroscedasticity problem.

Table 4. Classical Assumption Tes Results

\begin{tabular}{ccccccc}
\hline \multirow{2}{*}{ Normality } & Test & & \multicolumn{2}{c}{$\begin{array}{c}\text { Multicollinearity } \\
\text { Test }\end{array}$} & \multicolumn{2}{c}{$\begin{array}{c}\text { Heteroscedasticity } \\
\text { Test }\end{array}$} \\
\hline \multirow{2}{*}{$\begin{array}{c}\text { Kolmogorov } \\
\text { Smimov }\end{array}$} & $\begin{array}{c}\text { Asymp. } \\
\text { Sig }\end{array}$ & Variable & Tolerance & VIF & Sig Score & $\begin{array}{c}\text { Sig } \\
\text { Limt }\end{array}$ \\
\hline \multirow{3}{*}{0,076} & \multirow{2}{*}{0,200} & Leadership Style & 0,545 & 1,836 & 0,644 & 0,05 \\
\cline { 3 - 7 } & & $\begin{array}{c}\text { Organizational } \\
\text { Culture }\end{array}$ & 0,867 & 1,153 & 0,889 & 0,05 \\
\cline { 3 - 7 } & Job Satisfaction & 0,509 & 1,963 & 0,375 & 0,05 \\
\hline
\end{tabular}

To test the research hypothesis, the researcher conducted multiple regression analysis. This analysis used data obtained from the research instrument/questionnaire. Multiple regression test was administered with the help of the SPSS program. Testing the leadership style hypothesis on employee performance obtained t-statistics of 2.311 greater than t-table 1.670 with a significance of 0.025 less than a significance level of 0.05 . Therefore, it can be 
concluded that leadership style has a positive and significant effect on employee performance and accepts the first hypothesis. These results are in line with previous researchers who also found a positive and significant influence of leadership style on employee performance (Erniwati et al., 2020; Ohemeng et al., 2018; Zeb et al., 2015). The better the leadership style, the leader can empower his subordinates and ultimately the better the employee's performance.

This study supports the transactional leadership style theory in which the leader motivates employees to achieve organizational goals by promising rewards for good performance (Robbins, 2006). With this leadership that rewards employee achievements, employees at the Education and Culture Department of Yapen Islands Regency are motivated to provide the best performance. These results also support the research of Şen and Eren (2012) related to innovative leadership. Innovative leaders possess and utilize values to develop, communicate, and motivate followers to develop successful innovations (Şen \& Eren, 2012). Innovative behavior of individuals in the workplace is the foundation for highperforming organizations (Scott \& Bruce, 1994). Howell (2005) suggests that the success of an innovative idea is based on individuals emerging informally to promote the idea with confidence, persistence, and energy, and are willing to risk their position and reputation to ensure the success of the innovation.

The results of testing the second hypothesis show that the t-statistic value is $6.742>\mathrm{t}$ table 1.670 with a significance of 0.000 which is smaller than the 0.05 significance level. Therefore, it can be concluded that there is a positive and significant influence of organizational culture on employee performance and accepts the second hypothesis. This finding is in line with previous research which also found a positive and significant influence of organizational culture on employee performance (Altındağ \& Kösedağı, 2015; Asria \& Amali, 2018; Sulaefi, 2019; Ugheoke, 2019). The better the organizational culture, the more employees will be encouraged to improve their performance.

The organizational culture applied at the Education and Culture Department of Yapen Islands Regency is a supportive and role culture. Supportive characteristics are in accordance with the theory put forward by Robbins (2006) which explains that support from management is the extent to which leaders provide clear communication, assistance, and support to subordinates. It is also in accordance with the supporting cultural theory proposed by McKenna and Beech (2002). With a supportive culture, employees feel cared for and continue to be motivated by leaders who ultimately want to work hard to produce even better performance. Moreover, employees are given separate roles and are trusted to complete their work. By being given this trust, employees feel they are given responsibility and finally try to fulfill these responsibilities so that it has an impact on better performance.

Table 5. Results of Multiple Regression Analysis and Hypothesis Testing

\begin{tabular}{|c|c|c|c|c|c|c|}
\hline \multirow{2}{*}{\multicolumn{2}{|c|}{ Model }} & \multicolumn{2}{|c|}{$\begin{array}{c}\text { Unstandardized } \\
\text { Coefficients }\end{array}$} & \multirow{2}{*}{$\begin{array}{c}\text { Standardized } \\
\text { Coefficients } \\
\text { Beta } \\
\end{array}$} & \multirow[b]{2}{*}{$\mathrm{t}$} & \multirow[b]{2}{*}{ Sig. } \\
\hline & & B & Std. Error & & & \\
\hline 1 & (Constant) & 6,689 & 2,286 & & 2,926 & 0,005 \\
\hline & Leadership Style & 0,197 & 0,085 & 0,254 & 2,311 & 0,025 \\
\hline & $\begin{array}{l}\text { Organizational } \\
\text { Culture }\end{array}$ & 0,453 & 0,067 & 0,588 & 6,742 & 0,000 \\
\hline & Job Satisfaction & 0,116 & 0,087 & 0,153 & 1,341 & 0,185 \\
\hline & Adjusted R Square & 0,611 & & & & \\
\hline
\end{tabular}


Furthermore, the results of testing the third hypothesis in table 5 show that the tstatistic value is $1.341<\mathrm{t}$-table 1.670 with a significance of 0.185 , which is greater than a significance level of 0.05 . Therefore, it can be concluded that job satisfaction has no significant effect on employee performance and rejects the third hypothesis. This study is not in line with previous research which found a positive and significant effect of job satisfaction on employee performance (Ali \& Farooqi, 2014; Erniwati et al., 2020; Hendri, 2019; Mira et al., 2019).

No effect of job satisfaction on employee performance can be caused by many things. When viewed from the results of the descriptive analysis of respondents' answers, the statement with the lowest score is "You get the opportunity to use your own method in completing the given task" with an average value of 3.45. According to Weiss et al. (1964) one of the indicators in the Minnesota Satisfaction Questionnaire is the opportunity to use one's own method in doing a job. It shows that employees are not given the opportunity to use their own methods in completing tasks, even though their methods may be able to complete tasks better. Employees do not feel satisfied enough from the side or factors of their work (the work itself).

The statement with the next low score is "Benefits provided by the government in accordance with the workload" with an average score of 3.47. It shows that employees are not quite satisfied with the benefits or rewards provided, or the benefits provided are not in accordance with the workload they are doing. Whereas, reward is one of the most important factors in influencing employee job satisfaction and is always mentioned in various job satisfaction theories such as the theory proposed by Ranupandojo and Husnan (1995), Smith et al. (in Luthans, 2002), and Wexley and Yukl (1992). Salaries/wages include financial benefits received regularly, premiums, bonuses or other financial benefits. If employees feel that their salaries are sufficient and in accordance with their workload, employees will feel satisfied and will work better which results in high performance.

The results of this study support the research of Bercu and Onofrei (2017) that employee intrinsic factors are a priority. The main motivation for civil servants in realizing work performance is work stability followed by authority, responsibility and autonomy in work, comfort, advancement prospects, benefits packages, professional development, job attractiveness, and remuneration (Bercu and Onofrei, 2017). The lack of authority to do work using their own methods and allowances that are not in accordance with the workload causes employees at the Education and Culture Department of Yapen Islands Regency to not have enough job satisfaction which in the end does not significantly affect employee performance.

\section{Conclusion}

Based on the results of research that has been conducted regarding the influence of leadership style, organizational culture, and job satisfaction on employee performance, it can be concluded as follows: 1) The better the leadership style, the more the leader can empower his subordinates which can ultimately improve employee performance. 2) If the cultural values created by the organization are increasingly held by employees, the employee's performance will also increase. 3) Job satisfaction cannot explain the performance of employees at the Education and Culture Department, Yapen Islands Regency. Whether employees feel satisfied or dissatisfied, it will not affect their performance. 
The limitations of this study are that it was only conducted at the Education and Culture Department of the Yapen Islands Regency, so that it was less representative of all existing services in the Yapen Islands Regency and the small number of samples caused the results of this study to not be generalized to a wider research object. Furthermore, this study only used a questionnaire research instrument, not equipped with interviews so that it cannot explain in detail to support the results of quantitative analysis. Therefore, for further researchers, this research can be reconducted with different research objects and the number of samples is reproduced. Then, other variables or job satisfaction variables can be used as mediating variables to better explain their effect on employee performance. Regarding the leadership style, the leadership at the Education and Culture Department of the Yapen Islands Regency must maintain and improve the awarding of employees who excel and listen to the input and needs of employees so that they can further improve employee performance. In addition, leaders must also have good performance and can be role models for employees.

Moreover, the leadership at the Department of Education and Culture of the Yapen Islands Regency must pay attention to the organizational culture that is applied because these variables have a positive and significant effect on employee performance. The Department of Education and Culture of the Yapen Islands Regency should pay more attention to employee job satisfaction so that it has a significant influence on employee performance. Leaders at the Education and Culture Department of Yapen Islands Regency should provide more opportunities for employees to do their work according to their own methods and provide allowances that are in accordance with the workload given so that job satisfaction is met and ultimately can affect employee performance.

\section{References}

Ali, S., \& Farooqi, Y. A. (2014). Effect of work overload on job satisfaction, effect of job satisfaction on employee performance and employee engagement (a case of public sector University of Gujranwala Division). International Journal of Multidisciplinary Sciences and Engineering, 5(8), 23-30.

Altındağ, E., \& Kösedağı, Y. (2015). The Relationship Between Emotional Intelligence of Managers, Innovative Corporate Culture and Employee Performance. Procedia Social and Behavioral Sciences, 210, 270-282. https://doi.org/10.1016/j.sbspro.2015.11.367

Arnaboldi, M., Lapsley, I., \& Steccolini, I. (2015). Performance Management in the Public Sector: The Ultimate Challenge. Financial Accountability \& Management, 31(1), 1-22. https://doi.org/https://doi.org/10.1111/faam.12049

Asencio, H. (2016). Leadership, trust and organizational performance in the public sector. Transylvanian review of administrative sciences, 12(SI), 5-22.

Asria, M., \& Amali, H. (2018). The Influence of Job Involvement, Perceptions Of Organizational Support, And Organizational Culture On Employee Performance At The Village Community Empowerment Office Of West Sumatera Province. European Journal of Business and Management, 10(34), 84-90.

Babalola, S. S. (2016). The effect of leadership style, job satisfaction and employee-supervisor relationship on job performance and organizational commitment. Journal of Applied Business Research (JABR), 32(3), 935-946. https:/ / doi.org/10.19030/jabr.v32i3.9667

Bailey, J., Schermerhorn, J., Hunt, J., \& Osborn, R. (1991). Managing organisational behaviour. Brisbane: John Wiley and Sons.

Barney, J. B. (1986). Organizational Culture: Can It Be a Source of Sustained Competitive Advantage? Academy of Management Review, 11(3), 656-665. https://doi.org/10.5465/amr.1986.4306261 
Bercu, A.-M., \& Onofrei, M. (2017). The empirical research on civil servants' motivation: Evidence from Romania. Managing Global Transitions, 15(4), 399-417. https://doi.org/10.26493/1854-6935.15.399-417

Bird, F. (2001). Good Governance: A Philosophical Discussion of the Responsibilities and Practices of Organizational Governors. Canadian Journal of Administrative Sciences / Revue Canadienne des Sciences de l'Administration, 18(4), 298-312. https://doi.org/10.1111/j.1936-4490.2001.tb00265.x

Brewer, G. A., \& Selden, S. C. (2000). Why elephants gallop: Assessing and predicting organizational performance in federal agencies. Journal of public administration research and theory, 10(4), 685-712. https://doi.org/10.1093/oxfordjournals.jpart.a024287

Brown, A. D. (1998). Organizational Culture. London: Financial Times Management.

Budhwar, P. S., \& Sparrow, P. R. (1998). National factors determining Indian and British HRM practices: an empirical study. In Management and International Review (hal. 105-121). Springer. https://doi.org/10.1007/978-3-322-90989-3_7

Crossman, A., \& Abou-Zaki, B. (2003). Job satisfaction and employee performance of Lebanese banking staff. Journal of Managerial Psychology.

Erniwati, S., Ramly, M., \& Alam, R. (2020). Leadership style, organizational culture and job satisfaction at employee performance. Point Of View Research Management, 1(3), 918.

Fithriana, N., \& Adi, A. N. (2017). Dominant Effect Between Compensation, Leadership And Organizational Culture On Employee Performance Improvement. Journal of Applied Management (JAM), 15(4), 670-676. https://doi.org/10.21776/ub.jam2017.015.04.14

Ghozali, I. (2011). Aplikasi Analisis Multivariate Dengan Program SPSS. Semarang: Badan Penerbit Universitas Diponegoro.

Gibson, J. L., Ivancevich, J. M., \& Donnelly Jr, J. H. (1996). Organisasi: Perilaku, struktur, proses (Edisi kedelapan). Jakarta: Bina Aksara.

Hendri, M. I. (2019). The mediation effect of job satisfaction and organizational commitment on the organizational learning effect of the employee performance. International Journal of Productivity and Performance Management, 68(7), 1208-1234. https://doi.org/10.1108/IJPPM-05-2018-0174

Howell, J. M. (2005). The right stuff: Identifying and developing effective champions of innovation. Academy of Management Perspectives, 19(2), 108-119. https://doi.org/10.5465/ame.2005.16965104

Ibrahim, R., Boerhannoeddin, A., \& Kazeem Kayode, B. (2017). Organizational culture and development: Testing the structural path of factors affecting employees' work performance in an organization. Asia Pacific Management Review, 22(2), 104-111. https://doi.org/10.1016/j.apmrv.2016.10.002

Kreitner, R., \& Kinicki, A. (1992). Organizational Behavior. Irwin: Homewood, IL.

Leković, B., \& Marić, S. M. (2015). Measures of small business success/performanceimportance, reliability and usability. Industrija, 43(2), 7-26. https://doi.org/10.5937/industrija43-7209

Liana, Y. (2012). Iklim organisasi dan motivasi berprestasi terhadap kepuasan kerja dan kinerja guru. Jurnal manajemen dan Akuntansi, 1(2).

Lolowang, N. L., Troena, E. A., Djazuli, A., \& Aisjah, S. (2019). The effect of leadership and organizational culture on employee performance that is educated by motivation (study on the implementation empowerment programs in Jayapura city). Problems and Perspectives in Management, 17(1), 268-277. https://doi.org/10.21511/ppm.17(1).2019.23

Luthans, F. (2002). The need for and meaning of positive organizational behavior. Journal of Organizational Behavior: The International Journal of Industrial, Occupational and 
Organizational Psychology and Behavior, 23(6), 695-706. https://doi.org/10.1002/job.165

Mathis, R. L., \& Jackson, J. H. (2011). Human resource management: Essential perspectives. Cengage Learning.

McKenna, E., \& Beech, N. (2002). Human Resource Management: A Concise Analysis. Harlow: Financial Times Prentice Hall.

Mira, M., Choong, Y., \& Thim, C. (2019). The effect of HRM practices and employees' job satisfaction on employee performance. Management Science Letters, 9(6), 771-786. https://doi.org/10.5267/j.msl.2019.3.011

Nanwani, S., \& McIntyre, O. (2019). Independent Accountability Mechanisms: Promotion of Standards, Good Governance and Accountability. In The Practice of Independent Accountability Mechanisms (IAMs) (hal. 339-372). Brill | Nijhoff. https://doi.org/10.1163/9789004337787_015

Nasution, N. L. (2019). Analisis Loyalitas Kerja Pegawai Dinas Pendidikan Kabupaten Labuhanbatu. ECOBISMA (Jurnal Ekonomi, Bisnis dan Manajemen), 6(2), 1-13.

Ohemeng, F. L. K., Amoako-Asiedu, E., \& Obuobisa Darko, T. (2018). The relationship between leadership style and employee performance. International Journal of Public Leadership, 14(4), 274-296. https://doi.org/10.1108/IJPL-06-2017-0025

Panggabean, M. S. (2002). Manajemen Sumber Daya Manusia. Bogor: Ghalia Indonesia.

Patterson, M., Warr, P., \& West, M. (2004). Organizational climate and company productivity: The role of employee affect and employee level. Journal of Occupational and Organizational Psychology, 77(2), 193-216. https://doi.org/10.1348/096317904774202144

Pawirosumarto, S., Sarjana, P. K., \& Gunawan, R. (2017). The effect of work environment, leadership style, and organizational culture towards job satisfaction and its implication towards employee performance in Parador Hotels and Resorts, Indonesia. International Journal of Law and Management, 59(6).

Prawirosentono. (2014). Kepemimpian dan Motivasi. Jakarta: Ghalia Indonesia.

Puluhulawa, J. (2013). Regional Performance Allowance; Its Effect to Employee Performance and the Success of Local Government in Gorontalo Province, Indonesia. Public Policy and Administration Research, 3(12), 85-93.

Rahmatiah, D. J., Surya, I., \& Hasanah, N. (2019). Peranan Kepala Dinas Pendidikan dan Kebudayaan dalam Meningkatkan Kualitas Pendidikan Sekolah SDN 025 Di Desa Sungai Tuak Kecamatan Tanah Grogot Kabupaten Paser.

Ranupandojo, H., \& Husnan, S. (1995). Manajemen Personalia. Yogyakarta: BPFE.

Ravasi, D., \& Schultz, M. (2006). Responding to Organizational Identity Threats: Exploring the Role of Organizational Culture. Academy of Management Journal, 49(3), 433-458. https://doi.org/10.5465/amj.2006.21794663

Riduwan. (2002). Skala Pengukuran Variabel-Variabel Penelitian. Bandung: Alfabeta.

Robbins, S. P., \& Coulter, M. (2010). Manajemen. Edisi Kesepuluh. Jakarta: Penerbit Erlangga.

Sauer, S. J. (2011). Taking the reins: The effects of new leader status and leadership style on team performance. Journal of Applied Psychology, 96(3), 574-587. https://doi.org/10.1037/a0022741

Scott, S. G., \& Bruce, R. A. (1994). Determinants of Innovative Behavior: A Path Model of Individual Innovation in the Workplace. Academy of Management Journal, 37(3), 580 607. https://doi.org/10.5465/256701

Şen, A., \& Eren, E. (2012). Innovative Leadership for the Twenty-First Century. Procedia Social and Behavioral Sciences, 41, 1-14. https://doi.org/https://doi.org/10.1016/j.sbspro.2012.04.001 
Siengthai, S., \& Pila-Ngarm, P. (2016). The interaction effect of job redesign and job satisfaction on employee performance. Evidence-based HRM: a Global Forum for Empirical Scholarship, 4(2), 162-180. https://doi.org/10.1108/EBHRM-01-20150001

Spector, P. E. (2000). Industrial and organizational psychology: Research and practice. New York: John Wiley \& Sons.

Sulaefi, S. (2019). The Influence of Organizational Culture and Work Motivation toward Employee Performance at Lestari Raharja Hospital Magelang Indonesia. American Scientific Research Journal for Engineering, Technology, and Sciences (ASRJETS), 53(1), 145-163.

Tewksbury, R., \& Higgins, G. E. (2006). Examining the Effect of Emotional Dissonance on Work Stress and Satisfaction With Supervisors Among Correctional Staff. Criminal Justice Policy Review, 17(3), 290-301. https://doi.org/10.1177/0887403405282961

Trice, H. M., \& Beyer, J. M. (1993). The Cultures of Work Organizations. New Jersey, Prentice-Hall.

Ugheoke, S. O. (2019). Organizational culture and employee performance: moderation effect of transformational leadership style. Academic Journal of Business and Social Sciences, $3(1), 1-26$.

Vermeeren, B., Kuipers, B., \& Steijn, B. (2013). Does Leadership Style Make a Difference? Linking HRM, Job Satisfaction, and Organizational Performance. Review of Public Personnel Administration, 34(2), 174-195. https://doi.org/10.1177/0734371X13510853

Weiss, D. J., Dawis, R. V, England, G. W., \& Lofquist, L. H. (1964). Construct validation studies of the Minnesota Importance Questionnaire. Minnesota Studies in Vocational Rehabilitation.

Wexley, K. N., \& Yukl, G. A. (1992). Leadership in Organizations. Organizational Behavior and Personnel Psychology, 143-171.

Whittaker, J. B. (1995). Government Performance and Results Act of 1993. Virginia: Educational Services Institute.

Zeb, A., Saeed, G., Ullah, H., \& Rabi, F. (2015). Transformational and Transactional Leadership Styles and its Impact on the Performance of the Public Sector Organizations in Pakistan. Abasyn University Journal of Social Sciences, 8(1), 37-46. 